\title{
New media, youngsters and family: An emerging culture of changing communication practices in Indian families - a study in Delhi and NCR ${ }^{1}$
}

\author{
Namita Nagpal ${ }^{2}$ \\ Sarvesh Dutt Tripathi \\ Guru Gobind Singh University, India
}

DOI: 10.30547/worldofmedia.3.2019.1

\begin{abstract}
There is consensus among media and communication scholars that a monumental shift is occurring in the media and communication habits of young people, and the communication culture within family, is in a swirl. On the one hand, new digital media has progressively become a part of life in the urban cities and remote towns of India, governing the interactions of people, on the other, social media that developed as an off shoot of new digital media quickly became a big source of connectivity among the people, as across the globe. India has a special place on the social networking sites map owing to large numbers of its young users ${ }^{3}$. The usage of social networking sites amongst teenagers and college going students greatly increased with extensive influence on the youth in numerous ways, particularly as the new platform has scope to impact their interpersonal relationships. This triggered a debate on the impact of the new media on the activities, social relationships, and worldviews of the younger generations, and on values, attitudes, and patterns of social behavior, in the family context. The scope of enquiry of the present study is focused around two primary questions, i.e., 1) How is family communication influenced using new media (inclusive of social media? 2) Is family losing its place of importance in youngsters' lives?
\end{abstract}

${ }^{1}$ National Capital Region that includes 4 additional cities surrounding New Delhi, namely, Noida, Gurugram, Faridabad and Ghaziabad.

${ }^{2}$ Corresponding author:

Namita Nagpal, University School of Mass Communication, Guru Gobind Singh University, sector 16 'C' Dwarka, Delhi-78, India.

Email: namitanagpal@gmail.com

${ }^{3} \mathrm{https}$ ://economictimes.indiatimes.com/tech/internet/internet-users-in-indiato-reach-627-million-in-2019-report/articleshow $/ 68288868$.cms? from $=\mathrm{mdr}$ (discussed in Notes 1) 


\section{Keywords}

Teenagers, youngsters, family, peer group, new media, social networking sites, family communication culture.

\section{New media, family, and the youth as an integral part of family}

The term 'new media' in general refers to those digital media that are interactive, incorporate two-way communication, and involve some form of computing as opposed to 'old media such as the telephone, radio, and TV'. 'New media are new cultural forms which rely on computers for distribution: websites, human-computer interface, virtual worlds, VR, multimedia, computer games, computer animation, digital video, special effects in cinema and net films, interactive computer installations' ${ }^{\text {. }}$ Now, smartphones embedded with the Internet, social media, music, camera, video and sound recording in them are additional features. Lev Manovich proposed five 'principles of new media' - to be understood 'not as absolute laws but rather as general tendencies of a culture undergoing computerization', which were numerical representation, modularity, automation, variability, and transcoding'5. A key distinguishing feature of new media is interactivity, which describes the ability of users to provide content in response to a source or communication partner (Ha \& James, 1998). This provides audience members' control over content and its use. New media as a generic category covers all the above including social media ${ }^{6}$, which are sources of information/instruction, knowledge and entertainment to the people. However, the present study does not look at the new media merely as a vapid, deterministic, one way technology, but includes all the technological gadgets including desktop, laptop, iPad, and smartphone, etc., aided with the Internet, situated in the social mundane, processed and iterated in a cultural setting that shapes and gets shaped by its usage. It is the iterations with the 'social' and 'cultural' of the new media that this study is largely concerned about, the sociology of online engagements of family members and its repercussions in the family

\footnotetext{
${ }^{4}$ http//:www.manovich.net/Stockhol/stockholm_syllabus

5 https://nisfornewmedia.wordpress.com/2015/02/22/the-five-principles-ofnew-media/

${ }^{6}$ Boyd, D. M. \& Ellison, N. B. (2007). Social network sites: Definition, history, and scholarship. Journal of Computer Mediated Communication, 13(1), pp. 210-230. Available from: https://doi.org/10.1111/j.1083-6101.2007.00393.x (discussed in Notes 2).
} 
setting. New media includes usage and content of the Internet embedded in smartphone.

\section{Family in India}

The Indian family in this given context, forms the core of socialization, development of personalities and offers support system in a variety of ways, as family bonds and relational ties have lifelong existence. Family as a microcosm of society plays a major role in the development of the personality of an individual as an enviable support system, in and during crises periods. Working as shock absorber to pain, stress and depression of its members and providing a cushioning effect to spring back to normal activities, it is a cohesive and integral unit of the larger social systems. Though families in a large and culturally diverse country such as India may have plurality of forms that vary with class, ethnicity, and individual choices, but its members are bound by interpersonal relationships in a wider network of role and social relations. Family in India is undergoing vast changes and over time it has shown resilience to cope with the pressures of the modern life and is able to adjust and adapt to changing social norms and values. It has demonstrated a unique strength in keeping together despite the growing stress and strain. (Desai, 1995a; Sonawat, 2012; Sriram, 1993; Tata Institute of Social Sciences, 1993).

\section{Youth and adolescents}

The development of phenomenon of youth is seen by researchers 'as a site of secondary socialization developing clearer ideas of their future position in the social order,' and period of youth as 'plethora of transitional transitions' (Pedrozo, 2013). The youth were constructed as a social category shaped by social institutions regardless of young people's diverse experiences in terms of age, maturity, gender, class, and education (Evans \& Furlong, 1997; Forn s, 1995; Jones, 1988; Miles, 2000; Osgerby, 1998; Wallace \& Cross, 1990 ) in the 1970s and 80s. Livingstone (1999) pointed out the difficulty of capturing the meaning of youth in one term, 'with the post-1950s emergence of youth culture $\langle\ldots\rangle$ leading to childhood and youth becoming reconceived as connected but distinct phenomena'. Popular media accounts are based on adults' prescriptive views of youth attitudes and behaviours reflecting sociological perspective reporting/characterizing primarily, youth use of social media as overwhelmingly negative, and their engagements as reckless, unsafe behaviors with little thought to their online privacy or safety (Agosto \& Abbas, 2017). 
However, studies are undertaken now to explore the identity aspect using the psychological and sociological perspectives to look at the concept of adolescents and youth (Buckingham, 2013). Erikson therefore saw adolescence as a critical period of identity formation, where identity is developed by the individual, but needs to be confirmed by others. With increasing social competencies and skill, exploring different domains of movement digitally and challenging elders' authority becomes plausible. Erikson's notion of adolescence as a 'psychosocial suspension', in which young people's experimentations with different potential identities, and engagements with risks of various kinds (e.g., Internet) seems suitable in this respect. The psychological viewpoint may be juxtaposed with the sociological one, wherein a traditional, functionalist account of socialization treats the young person as a passive recipient of adult influences, a 'becoming' rather than a 'being' in their own right. The coining of category like 'Generation $\mathrm{X}$ ' and its subsequent mutations, reflects both the importance and the complexity of age-based distinctions in contemporary consumer culture. The present study precisely looks at this supposedly conflicting zone of psychological (personality development, peer group dependencies and digital immersion) and sociological wherein /familial/parental assumptions and expectations may work in opposite directions. However, the study includes young adults, i.e., the age group 19-22, to ascertain the difference in online usage of youngsters spanning 13-22 years of age.

The terms youngsters/young people/youth connote and convey this age bracket throughout the study interchangeably, except for the difference in using the terms teenagers/adolescents and young adults. The study has used the terms teenagers/adolescents as universally understood, that is, people who are in their teens/or people beyond 12 years but younger than 19-20 years of age. However, using the term 'young adults' has different meaning as adulthood is bestowed legally at 18 years to young people in India. Therefore, the young adults are addressed for people who are 18 years of age and above in the study. Though one may find differences even among early teenagers and late teenagers; and late teenagers are close to young adults as used in the present study. Youngsters are key important personalities in nuclear families in the urban settings, as they are always connected with an emotional cord with their parents. The present study aimed to find the new media usage of youngsters that included early teens and later teens and the young adults who are studying in school/college/ universities respectively, in order to observe the difference in their inclinations and preferences of new media practices in everyday life, and how it helps or intervenes to organize the family life. 


\section{Literature review}

Researchers have looked at the iterations with the new media of young users considering its negative aspects or the benefits and opportunities it provides.

\section{Identity, youth, and new media}

Youngsters/adolescents use social media for socializing and for communication and entertainment. Seeing themselves through the eyes of their imaginary ideated audience they tend to seek approval of their popular culture, entrenching in unreal standards of appearance, and falling prey to depression and anxiety. There are both risks and benefits to teenager's social and emotional development when it comes to the use of social media due to how embedded their lives are in it, implicating both the role of development on social networking site use, as well as the role of social networking site use on development iteratively (Cingel et al., 2014; Christofferson, 2016; Livsey, 2013). The studies undertaken in the Netherlands, the UK, the USA. Pakistan, Brazil and India, suggest both positive and negative effects of social networking use on adolescent self-concept which include strengthening of group identity, benefits of self-expression, and ability to reinforce social relationships, an intensified discrepancy between one's ideal and actual selves, false representations of the self, and the risks involved with online disclosure. In any case, identity, existence and everyday life of youngsters today is irretrievably layered with the new media. The results highlight the possibility of smartphone addiction (Gennaro \& Dutton, 2007; Manhas \& Chambyal, 2017; Nasir Ahmad et al., 2018; Pedrozo, 20137; Rallings, 2015)

\section{Youth as new media usage influencers}

Adolescents/youngsters influence the acquisition and use of the Internet at home which become major issues in family discussions and conflicts (Eynon \& Helsper, 2015; Rompaey et al., 2002) ${ }^{8}$ they might increase the engagement, digital skills and use of the Internet of parents and older adults in the family context in the adoption and use of the Internet and while children might influence uptake, btudies in the UK and Belgium were undertaken to find a co-relation between a globalised society with the pervasiveness of new media technologies in the fabric of society and being young.

${ }^{7}$ Pedrozo, S. (2013). Consumption youth and new media: The debate on social issues in Brazil.

${ }^{8}$ Rompaey, V. et al. (2002). Children's influence on Internet access at home: Adoption and use in the family context. 


\section{Parental mediation and monitoring ${ }^{9}$ of new media practices of youngsters}

The studies undertaken in Israel, the USA, Singapore, the UK, and India explored continued growth of Internet use among kids and adolescents. The online use is enhanced when education systems, health, support and other care and support services increasingly rely on new technologies, especially within the home. For the parents, the challenges come in the form of cyber bullying, easier ways to be contacted by strangers, and easier access to porn and other age-inappropriate content by the technological innovations/additions among youngsters (Livingstone \& Das, 2010). 'The alchemy between youth and digital media disrupts the existing set of power relations between adult authority and youth voice'. Parental mediation tends to diminish whereas peer mediation tends to escalate with age among teens which may increase teens' vulnerability to online risks. These may be improved, based on young people's reaction to the current mediation practices and may be more effective, within the social and cultural context of India. Shifting of technological gadgets from the public spaces of home to adolescents' and youngsters' private spaces, enhances their intensive utilization by them. Parental technological expertise may enhance their prestige in youngsters' eyes (Buckingham, 2008; Cho et al., 2005; Fletcher \& Blair, 2016; Jennings, 2017; Kumar 2016; Li \& Shin, 2017; Livingtsone, 2007; McMillan \& Morrison, 2006; Mesch, 2009; Nathanson, 1999; Shin \& Lwin, 2017; Vaidya et al, 2016).

\section{Family cohesion and new media}

The studies in the USA, Israel, and the UK suggest a correlation between new technologies into the household and changes in the levels of family cohesion. Frequency and type of Internet use are negatively related to family time and positively related to family conflicts, yielding a low overall perception of family cohesion. The new media technologies are negatively impacting social interaction between individuals within the household, leading to increased social isolation and privatisation of people's lives within the household. This impacts the cultural and moral values of families and personal lives, organising family life, leading to conflicts arising out of sharing of domestic details on the social media (Chambers, 2015; Little et al., 2009; Livingstone \& Bovill, 1999; Madianou \& Miller, 2012; McGrath, 2012; Mesch, 2006, 2009; Newham, 2012; Nie \& Erbring, 2002; Sponcil, 2012).

9 Jennings, N. (2017). In media and families: Looking ahead. Journal of Family Communication, 17(3), pp. 203-207. 


\section{Rationale}

The youngster, who was largely dependent on family has many goals to attend to now, and one of them is to keep the family, peer-group and her/his own inquisitions iterated through new media, satisfied. How the new media with its multi modal freedoms given to individuals has enhanced their aspirations needs to be investigated. How the family, which has been enacting the function of socialization, as a core social institution from centuries, is absorbing the new media in its fold, or whether the social networking sites have already taken up its role of socialization and put it on the margins? The central issue is, how it is influencing and shaping the communication patterns and interactions in the domestic. Livingstone \& Bovill (2001) argued that youngsters withdrew into the privatised world of their bedrooms, stacked more and more with the technological gadgets resulting in the 'privatization of young people's lives'. India as a society could boast of a family system that supported the individual in times of stress and distress and played an important role in her/his development. Family envelopes a youngsters' quotidian life every now and then. An enquiry therefore, was needed to ascertain how youngsters are assimilating new media in their lives, how their renovated communication culture determining the changes in the role and functions of the family and how the attendant influence of the social networking sites over the young members colouring the family interactions (Alzahrani \& Bach, 2014; Christofferson, 2016; Cingel \& Wartella, 2014; Livsey, 2013).

The present study looks at youth, comprising adolescents and young adults, as the core group of actors in the family, who define the family communication in ways not foreseen few decades back, becoming key persona in major decisions of the family and playing pivotal roles in everyday life and routine. Compared to their parents, they are digitally pivoted in that they are more likely to resort to their smartphones (Internet embedded) in multiple ways. They use it when exploring a topic for school or personal use, to read news on the Internet than in a printed newspaper; and to use online social network tools to meet friends and to find information. Their special relationship to digital media greatly influences the way they approach learning and interaction. This group of college and university students may be contrasted with school going early teenagers, whose approach of new media usage may be different from the late teenagers and young adults.

\section{Research questions}

There are two research queries. Firstly, what kind of role is the new media playing in the family life in terms of engagements? Secondly, if these engagements influence the family communications to impact family relationships in important 
ways. Largely, the scope of inquiry would shed light on the iterative engagement of young members with the new media, vis a vis, discounting, trading, or facilitating interactions within the family.

How is family communication influenced using new media inclusive of social media?

1. Is family losing its place of importance in youngsters' lives?

2. The study focuses on the two following objectives:

3. To determine how the youngsters, view mediation of their parents of their new media usage.

4. To ascertain the significance of family in youngsters' lives.

\section{Methodology}

\section{Research perspectives, design, and framework}

The theoretical prism is an intersection of developmental theory and uses and gratification theory. The research design is descriptive, as the objective is to describe the usage and attitudes of young users of new media and how this is bringing about a change in the family communication culture. Presently, the survey method answers the research questions.

The research enquiry was conducted with a survey and instrumented through a questionnaire which was carried out to generate a larger picture. The research methodology drew on the existing literature which provided a backdrop to initiate the argument. Later, the data generated from the primary research of survey illustrated the prevailing scene.

Sample taken from colleges and universities ensured diversities of demographics as students from all corners of the city come to one college or university. Therefore, convenient and purposive sampling with the desired age bracket (13-22) of school, college and university going youth using new media was used for the survey (online/ offline) in the NCR/Delhi. The participants who were tech savvy, comfortable using online method, filled up the google forms and those who wanted to answer offline were given the questionnaire to write their answers. The sample consisted of 310 male and 302 females divided into young age brackets, for the survey. The sample was drawn from schools, colleges and universities in East Delhi, North Delhi and South Delhi, NCR (Noida and Faridabad). Data was derived from some public schools that catered to middle or high-income groups, and from some government schools that catered to low-income group students. A total of 700 respondents were contacted and given/forwarded the forms, however, only 612 filled and returned the forms. The response rate was thus $87.4 \%$. The survey was conducted in 2017-18. 


\title{
Data analysis
}

Frequency analyses were employed to determine online engagements and usage of youngsters. A principal components factor analysis with varimax rotation was conducted to examine the dimensions of statements and to test the overlap of factors and a total of 29 statements were included in the first analysis, listwise, yielding a sample size of 612 . Following the results of the factor loadings, means, standard deviations, were computed for each factor. T-tests were employed to examine gender differences in the factors, and one-way Anova test was conducted on the age group, analyses were conducted to examine the relationship between social media usage of youngsters and family relationships.

\section{Demographics}

Figure 1

\section{Income group (class) \\ Per cent}

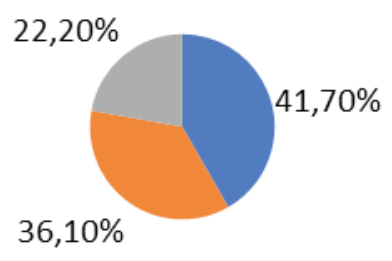

\author{
- less than 500,000 \\ Rs. \\ 500,000-1 million Rs \\ above 1 million Rs.
}

Note: 500,000 Rupees (Rs) equals 6,969.50 US dollar, 1 million equals 13938 USD.

Division/classification of sample age wise

Age groups

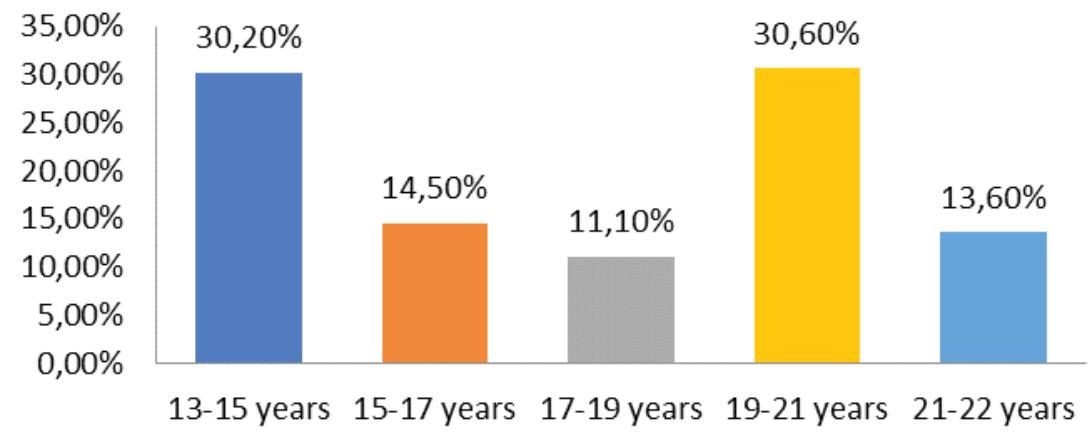


In the study the respondents were asked to respond the way they are using virtual media with different electronic devices.

\section{Online preferences and behaviour: Devices used and preferred}

The results indicate that majority of the respondents are using the virtual media with the help of smartphones. Approximately $93 \%$ of the respondents agreed that they are using smartphones for using virtual media, however, 7\% of the respondents say no to using smartphones for accessing new media. This is followed by using laptop by approximately $55 \%$ of the respondents, for going online. The results also indicate that desktop is no longer the preferred medium of accessing new media as close to $27 \%$ of the respondents agreed that they are using desktop for accessing new media. In today's scenario it is observed that most of the youngsters are carrying latest smartphones with them and due to the facility of Wi-Fi and $4 \mathrm{G}$ networks the accessibility of virtual media becomes very easy to access. The virtual media now offers different platforms and websites to the users. With the help of such web-sites the respondents can also participate via pictures, music, videos, comments, etc. with other participants. These platforms are providing a social community of the similar minded people where they can interact, share their feelings and also contribute in many ways.

\section{Social networking sites visited}

The results of the frequency distribution indicate the most used platform by the users, which is WhatsApp and Facebook, followed by YouTube, Snapchat and Instagram. However, very few of the respondents also use Twitter, Tumblr and Pinterest. The results indicate that WhatsApp is the most common platform used by respondents; this is due to the easy availability/configuration of the app in smartphones. After WhatsApp, Facebook is found to be second most used visual platform by the youngsters. It is observed that Tumblr, Pinterest, Periscope, Vimeo, Skype is used more by the students of high-end schools/colleges and students from the lower end of the spectrum do not use them, nor have any knowledge about these platforms. Economic class is a determining variable in developing the range of online expanse. 


\section{Social networking sites visited}

Figure 3

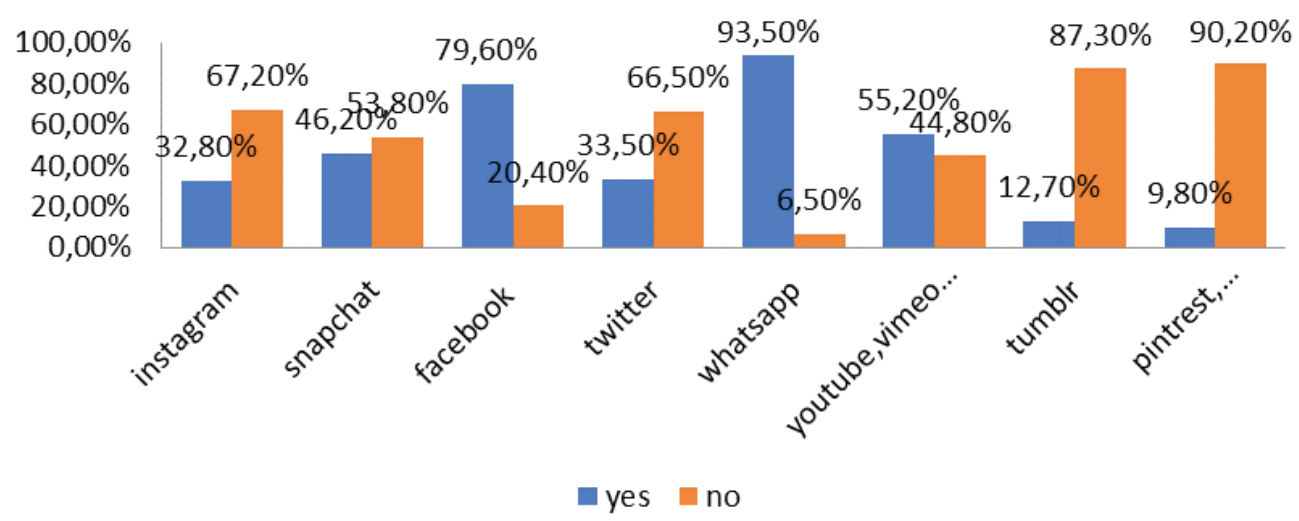

\section{Phone type preferred and broadband connectivity}

In the study, the respondents were asked to provide their preferences for using landline phone versus mobile phone. It is found that $88 \%$ of the respondents prefer mobile phone over the other for mobile phones give more comfort and privacy to the users (youngsters) as compared to landline phones (it encompasses all the uses with just a swipe). In addition to this, the mobile phones are found to have more flexibility and offer applications as compared to landline phones. The usage of landline phones is found to be almost negligible by the users. Broadband connectivity of the Internet at home denotes the networked facilitated area, the total expanse that facilitates not only mobile phones but desktop and laptops as well. In the study it is found that about $88 \%$ of the respondents do not have the broadband connection at home. This is because the relevance of broadband is coming down nowadays due to the smooth availability and better accessibility of Wi-Fi and 4th generation networks in the smartphones. While smartphones provide Internet access in seconds, it also ensures individualized space, in nutshell a big world in compact form, away from the prying eyes of elders at home, then accessing Internet in public space of the living room (Livingstone, $2005)^{10}$.

${ }^{10}$ Livingstone, S. (2005). Mediating the public private boundary at home: Children's use of the internet for privacy and participation. Journal of Media Practice, 6(1), pp. 41-51. 


\section{Age of acquiring mobile phone, frequency of going online, average length of each visit}

'Children being addicted to their mobile phones' seems to be the common complaint of most metropolitan parents in India today ${ }^{11} .69$ million children under the age of 18 residing in urban cities in India, 30 million have a personal handset and 11 million share it with one of their family members, while 28 million have no access to it (Ericsson, 2012 ) ${ }^{12}$. In the present study the respondents were asked the age at which they got their personal mobile phones. The results indicate that maximum respondents got their mobile phones either at high school or senior secondary levels followed by $20 \%$ who got it at the middle level. Gifting mobile phones to their young ones, as early as at primary level, is still not a regular practice by parents in India as compared to kids in developed countries where average age of acquiring smartphone has gone down to 10.3 years on an average ${ }^{13}$. Also, there is a visible percentage of those who do not own a mobile phone but manage with either of their parents' phone. There are some who got their first mobile at the college level. Boys generally get mobile at an earlier stage than girls, reasons of which may be culturally seeped into the Indian society which has a penchant for the males, hence the preference and priority to boys in buying gadgets as well (Klaus \& Tipandjan, 2014) ${ }^{14}$.

\section{Age of acquiring phone}

Figure 4

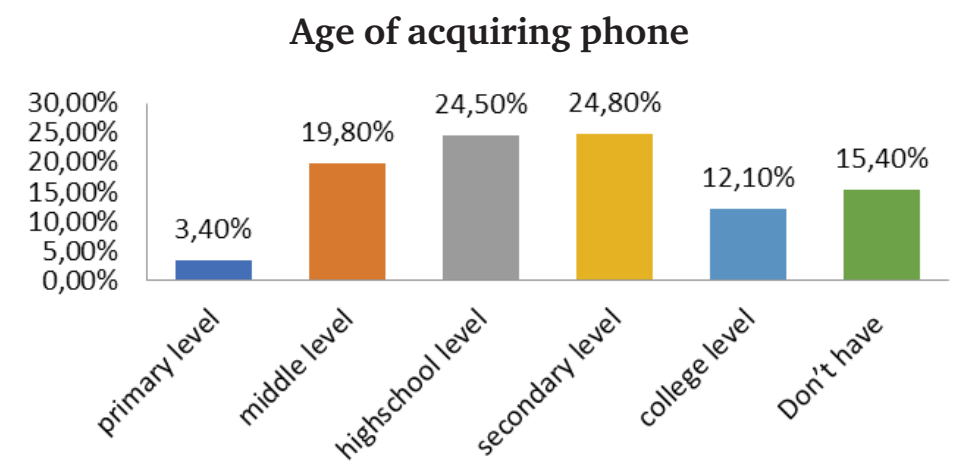

${ }^{11}$ Children's use of mobile phones - an international comparison 2011. Available from: https://www.gsma.com/publicpolicy/wp-content/uploads/2012/03/Childrensuseofmobilephones2011.pdf

${ }^{12}$ http://www.afaqs.com/news/story/35922_30-million-urban-Indian-childrenown-personal-mobile-phones

${ }^{13}$ Kids and tech; the evolution of today's digital natives. Available from: http:// influence-central.com/kids-tech-the-evolution-of-todays-digital-natives/

${ }^{14}$ Son preference in India: Shedding light on the north-south gradient. Comparative Population Studies, 40(1), 2015, pp. 77-102. 
Smartphones have become constant companions to the youngsters. For a variety of reasons, they reach out to their smartphones. More than $70 \%$ of them keep looking at their smartphones, either to check updates, or to satiate their curiosity, or being in touch with their friends and family. Therefore, for most, going online for most part of the day is routinized. However, they do not admit spending longer durations online. Most students do not admit using the Internet for longer hours as close to $63 \%$ admit of spending less than one hour to two hours. Very few (a miniscule 3.5\%) acknowledge that they access content on the Internet for more than 6 hours.

Figure 5

Time spend online by the youngsters

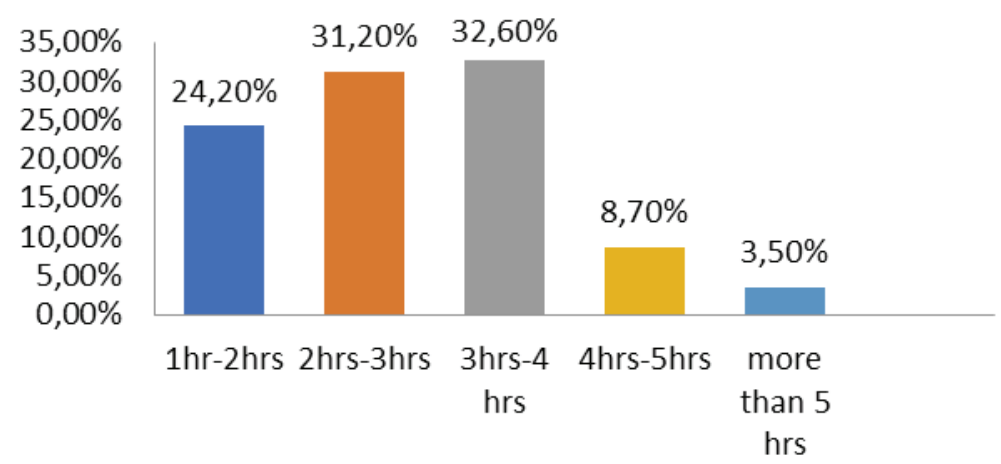

\section{Discussion $^{15}$}

The primary data is collected with the help of questionnaire method and analysed using EFA, frequency distribution, descriptive analysis and reliability analysis. The youngsters selected in the study were asked to provide the responses against the statements related to the expected changes in their family life as a result of their exposure and involvement with the social media networking web-sites. In the study, twenty-nine statements are included using seven-point Likert scale, representing different possible influence of online social media in the family life of selected students. The respondents were asked the statements, and they could rate each item on a 7-point Likert-type scale ( 1 for strongly disagree, 7 for strongly agree).

The results of PCA indicate that five extracted factors can explain 66.9\% of the variance in the included twenty-nine statements. In PCA the first factor

${ }^{15}$ For statistical description and analysis, see the Appendix. 
explains maximum variations in the statements (20\%) followed by $16 \%$ by second factor extracted in the study and so on. The results of rotated component matrix indicate the five factors extracted along with statements with high factor loading. On the basis of subjective judgment these five factors are named as: 1) new media, personality and family, 2) emotional space, family vs new media, 3) parental control on youngsters' new media use 4) family together time and new media, and 5) youngsters personal space vis a vis parents' personal space.

\section{New media's impact on personality vis a vis family}

The high mean scores of statements in this section, bring out how social and new media are influencing the young minds, immersed deeply in their routine and how it directs and controls their behaviour and attitude as checking phones every now and then has become their second habit and expecting response from family members at the Internet speed, is the new norm. It is the attachment with the device they think now is indispensable to them as many believed 'parents own levels of media and technology use affect the use patterns of new media by children at home'. It reveals what importance youngsters attach to their parents' digital expertise. Youngsters credit new media for making career choice, learning social skills and interacting with the foreign culture over their parents or family. Social media score over family in that it gives them more knowledge and better exposure to the choices/decisions they need to make outside the domestic purview. Many youngsters admit that social media is the ground where they have been ridiculed or bullied by their peer group, but that does not give them reason enough to withdraw from using it. However, Internet usage seems to have brought about behavioural difference gender wise as more females than males expect immediate/swift response from family members on the line of Internet ('I expect immediate response from my family and friends just as Internet gives me instant answers to my queries' for the females is 5.0, and that of male is 4.7'), this shows their tolerance level at a lower level than males. The inquiry brings to light that new media has come to influence their lives, attitudes and behaviour profoundly. It is increasingly becoming a window to their world, replacing some conventional functions of the family and in doing so, the role of new media and of social network sites in young people's lives is getting integrated.

\section{Family together time and new media}

Parents might be concerned about the digital world's negative influence over the youngsters, with all the alerts, texts, tweets, calls and instant messages it 
brings. But how do youngsters look at this new media consumption eating into family together time? Most of the participants affirm that 'negotiating media use causes conflicts in their homes'. An increasing number of young people admitted their use of the Internet, including social network sites, is eroding the time they spend with their family. Other studies previously deduced this ${ }^{16}$. The statement confirms this 'If social network sites like Instagram/Snapchat/ Facebook did not exist then I would spend more time face to face with my family' (mean score -4.8). Youngsters being more connected than ever in the digital age as they generally think that the time, they spend on virtual reduces the amount of time they spend communicating with family face to face (mean score -4.4 ). Face to face family communications are a preferred choice as all the statements favouring face to face family communication have higher mean scores than the one favouring new and social media. Though spending time on new media is a habit now in the event of absence of social networking sites, the youngsters wish to spend more time with their families. Perhaps, the new media usage is associated with enhancing networking. The youngsters living in nuclear families tend to think that those living in the joint/extended families do not much need to spend their time on new media as already they are living in joint families implying in a sense that they do not have to think about how to pass their time. Joint family has a network of relations, more siblings, more elders, where one is always surrounded by the family members. It is people living in nuclear families that need smartphones. There was difference in mean scores of early teens and young adults as the mean scores of young adults and older teens (18-22 years) were higher for the 1st, 2 nd, and 3rd statements as compared to the mean scores of early teens (13-15 years) whereas the means score of the 5 th statement of early teens was higher than the late teens and young adults ${ }^{17}$.

\section{Parental control, new media, and youngsters}

The family in India may be little different from the families in other parts of the world, in that how the youngsters deal with their parents, and family's presence in youngsters' lives. Their responses inform that they do not interpret that family is

${ }^{16}$ Anderson, M. (2016). Parents, teens and digital monitoring. Available from: http://www.pewinternet.org/2016/01/07/parents-teens-and-digital-monitoring/; Gaudin, S. (2009). Social networks cutting into family time; Increasing use of social networks are making users less social with their families. Available from: https:// www.computerworld.com/article/2525517/internet/social-networks-cutting-intofamily-time.html

${ }^{17}$ To see the statements, please see the Appendix. 
poking its nose in their affairs. All the statements (except 2 and 7) that are critical of family intervention get minimum mean scores implying the youngsters are not always averse to parental interventions or supervisions of their online activities. They do not mind if parents supervise their online behaviour, nor they find it invasive or intrusive, parental interjections may be irritating when they are busy on their phones, yet they perhaps understand and appreciate that all this supervision is about their safety and security. However, there is a slight difference in male and female perception to family interruptions when they are occupied in their smartphone activities, as they take it differently, females do not get upset mean score 3.8, and that of males is 4 , that is females do not much think of family members interrupting them whereas males do not like family interrupting them when they are busy on their phone/Internet activities. Nevertheless, they do not approve parents wanting to know all their online activities (mean score - 3.5) and sharing their digital device (smartphone or laptop) is not a good idea (mean score is 4.2). There was difference in perception across age brackets as well, as mean scores in the age group of 13-17 for statements 1, 3, 5, and 6 which favor youngsters' independence from parental supervision, and statements 2,4 , and 7 that favour mediation and monitoring, were higher than the age group from 17-22 years.

\section{Youngsters personal space vis a vis parents' personal space}

Teenagers not only get their needs to be listened to and noticed in this peer public but admired sometimes when that peer public is made online. If the family cannot provide them a situation where their needs are noticed or listened to and the need to be loved are met, then, they in turn will look for its fulfilment in social media as other alternatives (Boyd, 2008; Elkind, 1967; Varghese \& Nivedhitha, 2014 ${ }^{18}$; Warner, 2004). The following statistics explain an Indian youngster better, (s)he is happiest in her/his bedroom checking the latest updates on her/his mobile as the mean score illustrate (at 4.1) Interestingly, when it comes to their perception of their parents' usage/addiction the youngsters find it annoying. They are not tolerant to their parents if they indulge with their smartphones, as they are vexed at finding their parents glued to their own mobile phones (mean score is 4.1), which implies there is sufficient number of youngsters who get frazzled when they find parents occupied on their smartphones. And this is an interesting aspect of their disposition; that they want to deny the same freedom to their parents they themselves want to enjoy.

${ }^{18}$ Varghese, T. \& Nivedhitha, D. (2014). Indian teenagers and their family relations in the social networking era. Rajagiri Journal of Social Development, 6(1), pp. 29-48. 


\section{Emotional space, family vs new media}

Contemporary youth are growing up in a cultural setting in which many of their experiences and opportunities are shaped by their engagement with social network sites. Subsequently, questions and controversies emerge about the effects social network sites have on their development due to how embedded their lives are in social media, and its repercussions on family life. However, it emerges from the present study that youngsters believe providing emotional support is their family's prerogative, as all the mean scores are maximum in favour of family providing emotional and psychological care. In a wide spectrum of providing emotional sustenance during times of illness, loneliness, distress and sharing happiness, family comes first. Wishing family members through social media minus physical warmth is not their first choice. Nevertheless, the female perception of loneliness when the family is not around, despite the social media, is little greater than the males (mean score of females is 5.1, whereas that of males is 4.9). Correspondingly, the females give more weightage to family in times of distress as the best stress buster than the males (mean score females 5.3, whereas that of males is 4.8). This underscores the priority that females give to the concept and existential importance to 'family'. From the overall mean scores, it is evident that family scores better in terms of giving emotional support to youngsters, that they are not yet alienated in their own world and need familial presence and psychological sustenance from their family, as all the activities, that gives them support or relief, sentimental transactions receive some higher thumbs up than familial communication mediated through virtual media. There was no significant difference of opinions across age- groups in the perception of the idea of family function of providing psychological and emotional care and sustenance to youngsters.

Has new media, including social media, influenced family communication? The answer is largely in positive, for it fulfils many tasks in the mundane of a youngster of today. When it got structured in the quotidian, it was imperative that it replaced some functions of family, that it was always performing. The new media has influenced family communication culture in profound ways. It now plays the role of guide, instructor, educator and trains young people to face the world, all the functions that were performed by the family in not so distant a past. 


\section{New media's gain vs family's loss}

\section{New media takes over family functions}

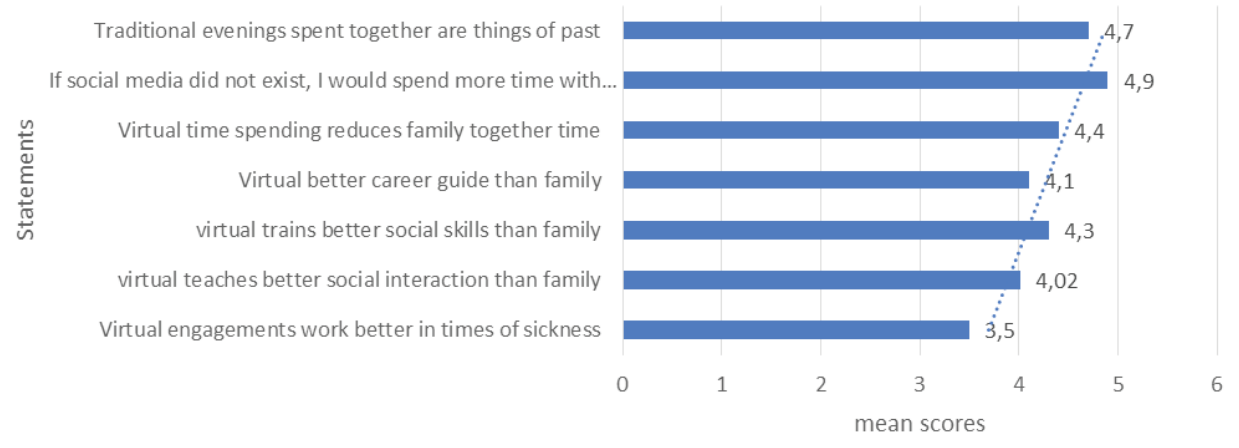

Figure 7

\section{Youngsters' interpretation of family communication culture}

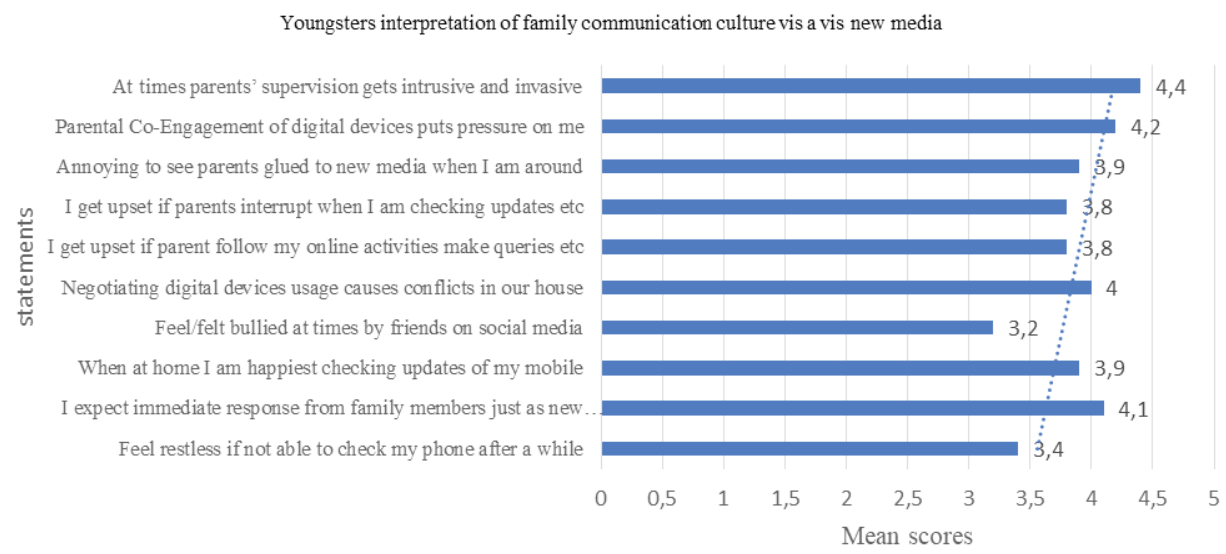

As technology enters the domestic and comes to perform family's functions, tension may arise for the device gets integrated and consumes time of family members. Parental monitoring may not be accepted readily by the youngsters, and there may be other undulations in their routine and behaviour. Despite the conflicts and tensions, youngsters have given new media through their smartphones, a primacy of space in their lives. It is understandable as it sates their everyday investigations without inquisitions and preaching. 
Figure 8

\section{Family communication culture least influenced by new media}

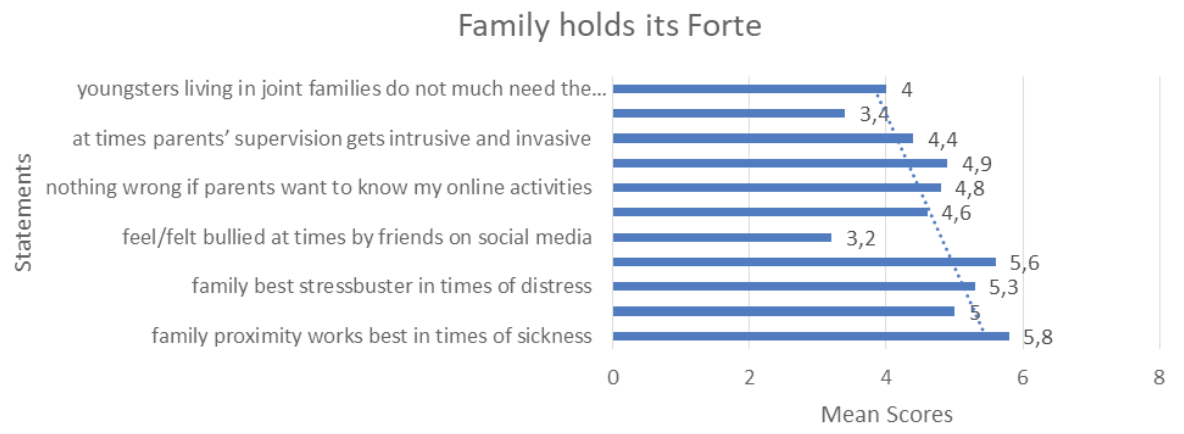

Therefore, one may assume that new media has almost family for the plethora of functions and utilities it has in young people's lives. As of now, family holds its forte because it has certain sacred efficacies in the lives of youngsters that it cannot find in social and new media. Values and utilities that only family may offer. A technological gadget with all its interactivity, services and conveniences, may not replace the warmth, support and care of human relationships.

\section{Theoretical perspective}

Erikson's model provides a theoretical framework to explore issues of selfesteem, belonging and identity. While the 'self-esteem and identity' issues may co relate with peer group and new media, the family may provide 'belonging' to youngsters. Erikson's Stages of psycho-social development posits adolescent development occurring primarily through identity formation within the context of social relationships consisting primarily of family and friends, where new and social media is indispensable part. New media plays a crucial role as it enters their lives when their world is in a state of transitional flux. Being exposed to the vast new world of friends, new media and their own body and mind, youngsters try to adjust themselves to the new orientations, and fine tune to demands and expectations of the peer group and family (Erikson, 1968; Frydenberg, 2008; Manago et al., 2012; Moshman, 1999; Steinberg, 2005). Social networking sites greatly influence the formation of individual identity through digital communication and interaction with peers. In today's time, when peer group plays an important role in youngsters' lives, and with new media becoming omnipresent, its role assumes significance as a shaper of personality development in the mundane. The role of peer group needs to be underscored as social media plays out all the interactions and iterations in a youngster's life through it 
(Leung \& Wei, 2000; Qi et al., 2017). Youngsters turn to one another, instead of their families, as their first line of support during times of worry or upset. This increased reliance on friendships may well be another reason that youngsters assert for private spaces that includes ownership of smartphones that helps them glue together with friends on social media. Thus, enabling them to bond over shared experiences with the Internet and smartphone mediating and facilitating in building up a conducive environment for interaction and relationships. In general, social media with its interactive features helps youngsters to gravitate toward peer groups with whom they share common interests.

The personality development theory is aided by uses and gratifications theory (Quan-Haase \& Young, 2010) as a key distinguishing feature of new media is interactivity, which describes the ability of users to provide content in response to a source or communication partner (Ha \& James, 1998). Youngsters enjoy their position as producer of information. The uses and gratifications theory may apply to all youngsters as they feel gratified when they use the new media in terms of generating content and satisfying their inquisitions on a range of subjects, by consuming the content and later sharing with their peers or family members. This provides them control over content and its use, making it important to examine the gratifications new media provide to users in comparison to traditional media (Lin, 2001; Toffler, 1980). Youth psychology of generating social media content is closely related to her/his gratifications, when (s)he uses it to mark her/his authorship, hence his personality.

\section{Conclusion}

Situated in the mundane of family, the online engagements may demand adjustments, assertions or a middle path where authorities are challenged/ defied or there may be role reversals. 'Over the years, families have transitioned from finding ways of turning off the media to learning strategies to cope with and navigate media in our lives' with understanding from both sides, parents as well as children' (Jennings, 2017). The study has brought to light some interesting results like appreciation of new and social media's role in personality/skills/competencies enhancement by all age groups and gender, which were considered family responsibility. However, age and gender emerge as significant variables in perceiving role and importance of family and new media. The early teens in general resent parental control and monitoring of their online activities, later teens and young adults understand and appreciate parental concerns. Early teens are critical of parental online usage whereas young adults are tolerant. They associate their privacy and independence with 
their online usage and prefer it than their seniors. Gender-wise, the results do not show marked difference, yet females associate loneliness with the absence of family more than males. All the same, family is important to them and take precedence in matters of emotional sustenance and being together time.

Studies carried out across globe including the USA, the UK, Europe, Asia have looked at the youngsters' engagements and conflicts arising thereafter in the family, however, the meaning and relevance of this study may be different for the family in India as it signals arrival of new media in the domestic domain and overtaking some of the important functions of the family, thus cutting down the role of family in blooming lives. Technology is here to stay, and the family must adapt itself to be in sync with the changing times and with youngsters. Their itch for privacy may be universal, but it is worth noting that youngsters consider parental control and monitoring as necessary part of parenting. There is a scope for further exploration to ascertain parental viewpoints and how they monitor the Internet activities of the young ones. Family communication and relationships may further improve if there is more transparency of the Internet activities and both the sides need to understand points of views of each other. This study has provided a theoretical framework for understanding youngsters' practice and usage of new media in the domestic and an emerging change in communication culture therein ${ }^{19}$.

19 1) India's Internet users expected to register double digit growth to reach 627 million in 2019 with an annual growth of $18 \%$ and is estimated at 566 million as of December 2018, a 40\% overall Internet penetration. It projected a double-digit growth for 2019 and estimates that the number of Internet users will reach 627 million by the end of this year. Of the total user base, $87 \%$ or 493 million Indians, are defined as regular users, having accessed Internet in last 30 days. Nearly 293 million active Internet users reside in urban India, while there are 200 million active users in rural India, it said. The report found that $97 \%$ of users use mobile phone as one of the devices. Provided by market research agency Kantar IMRB;

2) Boyd \& Ellison defined 'social network sites as web-based services that allow individuals to (1) construct a public or semi-public profile within a bounded system, (2) articulate a list of other users with whom they share a connection, and (3) view and traverse their list of connections and those made by others within the system. The nature and nomenclature of these connections may vary from site to site. While the term "social network site" is used to describe this phenomenon, the term "social networking sites" also appears in public discourse, and the two terms are often used interchangeably'. Social media used for sociality and social networking is a part of new media which is an all-encompassing term for technological gadgets and network. 


\section{Appendix I}

Table 2 depicts wording, means, and standard deviations for each item. In order to classify the different type of impacts the social media have on the family life of young generation, the EFA method using principal component method and varimax orthogonal rotation is applied in the study. The EFA technique helps in exploring the latent factors representing similar influence of the social media on the family life of the students. The EFA method requires the fulfilment of few assumptions, namely the sampling adequacy and the presence of correlation among the different sets of included statements. The sampling adequacy represents the presence of sufficient variations in the responses received against the statements. The presence of sufficient sampling adequacy is tested with the help of KMO tests where the expected value of KMO statistics is greater than 0.6. The Barlett's test of sphericity is used to analyse the coefficient of correlation between the different pairs of statements included in the analysis. The Bartlett's test examines the null hypothesis that the estimated correlations matrix representing the coefficient of Pearson correlation between the different pairs of statements is an identity matrix. The results of KMO test as well as Barlett's test of sphericity are shown below.

Table 1

Results of KMO and Bartlett test in EFA

\begin{tabular}{|c|l|c|}
\hline \multicolumn{2}{|c|}{$\begin{array}{c}\text { Kaiser-Meyer-Olkin (KMO) } \\
\text { estimate of sampling adequacy }\end{array}$} & 0.938 \\
\hline \multirow{3}{*}{ Bartlett's Test of Sphericity } & Chi-Square statistic & 11656.244 \\
\cline { 2 - 3 } & Degree of freedom & 406 \\
\cline { 2 - 3 } & Significance value & .000 \\
\hline
\end{tabular}

The result indicates that the KMO statistics is found to be 0.938 which is greater than minimum expected value of 0.6 . Therefore, it can be concluded that the condition of sampling adequacy is fulfilled. Also, the probability value of Chi Square statistics in case of Barlett's test of sphericity is found to be five percent level of significance. Hence with 95 percent of confidence level the null hypothesis that 'The correlation matrix is an identity matrix', cannot be accepted. Therefore, it can be concluded in the study that there exists significant correlation between the different pairs of included statements in the factor analysis. Thus, factor analysis may have significant contribution in fulfilling the purpose of the study. In the process of principal component analysis, the eigen values of different components are estimated and arranged in the descending order. Only 
the factors with eigen value more than 1 are selected for further study. The PCA method arranges the factors as per the decreasing order of eigen values i.e. in this process, the component with the highest eigen value comes first and the next component with second highest value comes after that. The eigen values are estimated before and after the varimax rotation. The results of EFA indicate that the twenty-nine statements related to the impact of social media on the family life of young students included in the EFA analysis can be further reduced to five significant extracted factors. These extracted factors are selected on the basis of criteria of eigen values greater than one. In EFA method, the orthogonal varimax rotation is also applied on the extracted factors in order to increase the explanatory power of the different extracted factors. The varimax rotation helps the researcher in getting the independent and uncorrelated factors and also helps in better explaining the latent factors extracted from the process of EFA. The factor loadings of different statements to different extracted factors are estimated and shown in table. The factor loadings represent the coefficient of Pearson correlation between the different included statements and factors. In EFA method it is expected that each statement should have high factor loading to one single factor and low factor loadings to remaining factors. The statements in the EFA having different factor loadings to different factors are sorted with respect to their factor loadings in descending order. This helps in locating the statements having high factor loadings to a specific factor. In addition to this, the communality of different statements is also estimated which is similar to the coefficient of determination $\left(\mathrm{R}^{2}\right)$ and indicates the percentage of variance of the statements explained by extracted factors. The result of rotated component matrix is shown below. 


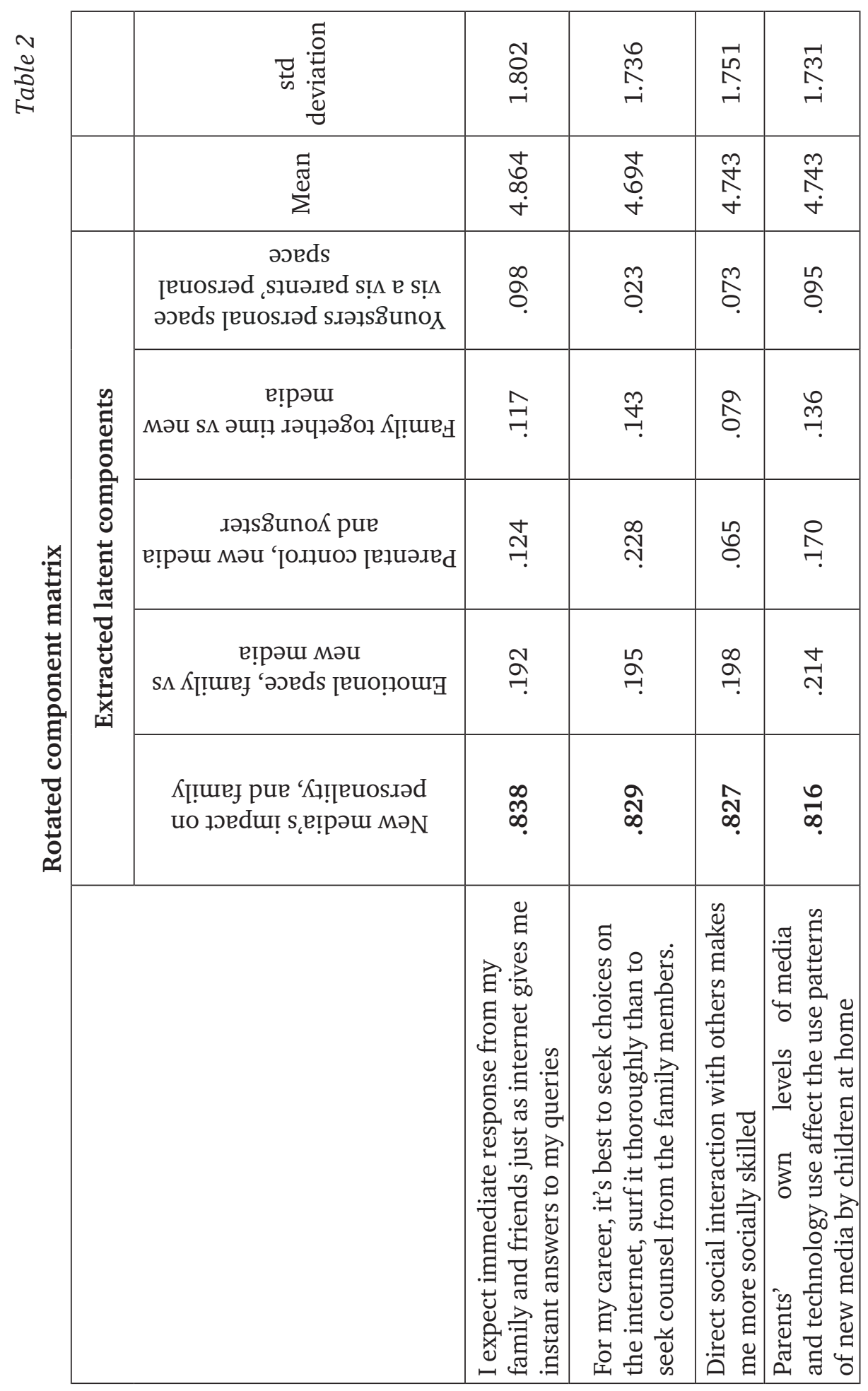




\begin{tabular}{|c|c|c|c|c|c|c|c|c|c|}
\hline $\begin{array}{l}\text { ్ֶ } \\
\stackrel{+}{-}\end{array}$ & 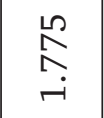 & $\begin{array}{l}\stackrel{2}{\curvearrowright} \\
-i\end{array}$ & 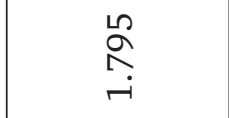 & 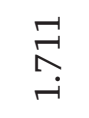 & $\begin{array}{l}\underset{N}{\hat{\sigma}} \\
-\end{array}$ & 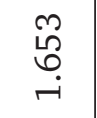 & $\begin{array}{c}\infty \\
\stackrel{\infty}{\stackrel{\Gamma}{r}}\end{array}$ & 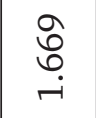 & $\begin{array}{l}\hat{\infty} \\
\infty \\
\text { - } \\
\end{array}$ \\
\hline $\begin{array}{l}\stackrel{2}{O} \\
+ \\
\dot{\sigma}\end{array}$ & $\begin{array}{l}\stackrel{2}{O} \\
\stackrel{+}{+} \\
\dot{\gamma}\end{array}$ & $\begin{array}{l}\text { Oे } \\
\stackrel{+}{+}\end{array}$ & $\begin{array}{l}\underset{\varpi}{\sigma} \\
\stackrel{\nabla}{\sigma}\end{array}$ & 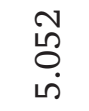 & $\begin{array}{l}m \\
\vec{\nabla} \\
\dot{m}\end{array}$ & $\begin{array}{l}\text { Oे } \\
\text { Oे } \\
\text { in }\end{array}$ & $\begin{array}{l}\underset{F}{F} \\
\underset{\sim}{*}\end{array}$ & $\begin{array}{l}\hat{\omega} \\
\text { m. } \\
\text { Ln }\end{array}$ & $\begin{array}{l}\infty \\
\sigma \\
\sigma \\
\dot{m}\end{array}$ \\
\hline gे & $\stackrel{\infty}{\sigma}$ & $\begin{array}{l}1 \\
\text { o } \\
0\end{array}$ & 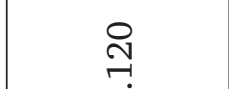 & శ్రి & $\hat{\emptyset}$ & 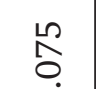 & ஓे & ণิ & $\vec{\sigma}$ \\
\hline مิ & ণั & $\underset{r}{\stackrel{g}{r}}$ & 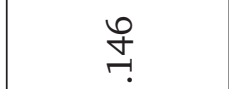 & 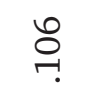 & ğ & $\stackrel{m}{=}$ & ๖̊ & 움 & $\underset{\neg}{\stackrel{f}{*}}$ \\
\hline $\begin{array}{l}\text { ڤొ } \\
\text { ஸ़ }\end{array}$ & คे & ஸે & $\underset{\sim}{\stackrel{+}{*}}$ & $\hat{a}$ & ڤે & 곡 & 옴 & 롬 & $\underset{\infty}{\infty}$ \\
\hline 동 & 曷 & $\stackrel{\circ}{\circ}$ & $\hat{\sigma}$ & $\underset{\hat{\infty}}{\stackrel{N}{~}}$ & 亡ீ: & $\begin{array}{l}\infty \\
\infty \\
\infty\end{array}$ & হั & ֻొ & ช్ర \\
\hline হ̄ & ઼ָ & $\stackrel{\infty}{\stackrel{\infty}{N}}$ & $\begin{array}{l}\text { L } \\
\stackrel{0}{0}\end{array}$ & 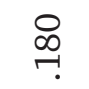 & 守 & $\stackrel{\infty}{\stackrel{\infty}{r}}$ & $\underset{r}{\stackrel{J}{r}}$ & $\stackrel{⿱ 亠}{\sim}$ & $\begin{array}{l}\text { రै } \\
-1\end{array}$ \\
\hline 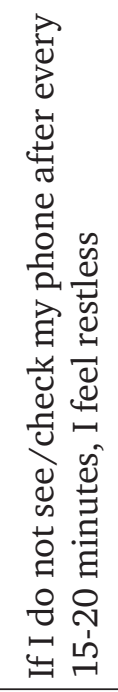 & 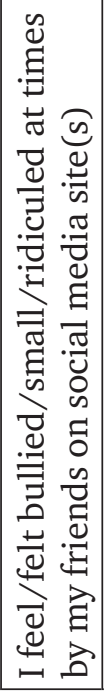 & 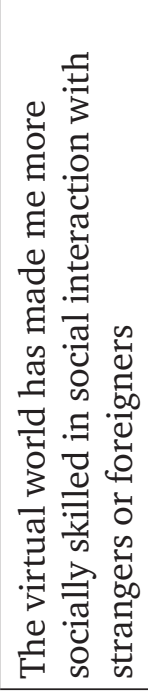 & 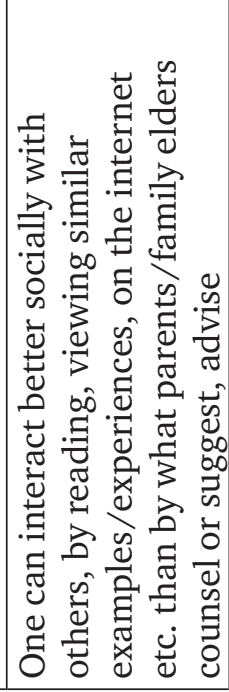 & 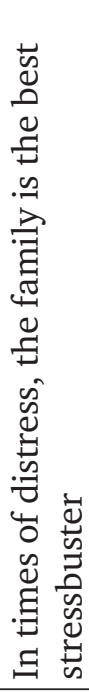 & 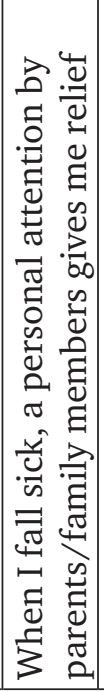 & 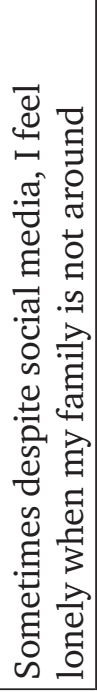 & 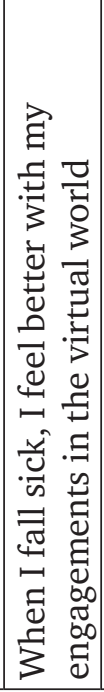 & 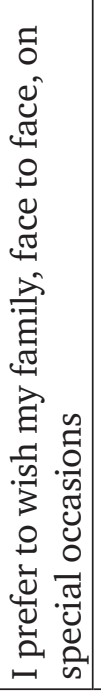 & 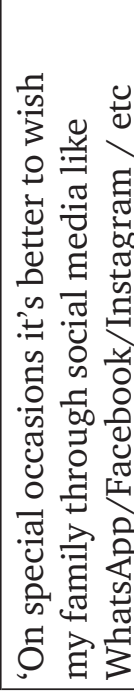 \\
\hline
\end{tabular}


Namita Nagpal, Sarvesh Dutt Tripathi

\begin{tabular}{|c|c|c|c|c|c|c|c|c|}
\hline $\begin{array}{l}\hat{b} \\
\infty \\
- \\
-\end{array}$ & $\begin{array}{l}\infty \\
\stackrel{\infty}{\infty} \\
\infty \\
- \\
-\end{array}$ & $\begin{array}{l}\infty \\
\infty \\
\infty \\
\stackrel{+}{-}\end{array}$ & $\stackrel{\overrightarrow{\widehat{\sigma}}}{\stackrel{-}{-}}$ & تُ & $\begin{array}{l}\text { m } \\
\infty \\
\stackrel{\infty}{-}\end{array}$ & 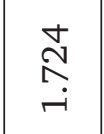 & $\begin{array}{l}\stackrel{+}{\hat{\sigma}} \\
\stackrel{\sim}{-}\end{array}$ & $\begin{array}{c}\stackrel{m}{\curvearrowright} \\
\stackrel{\sim}{r}\end{array}$ \\
\hline $\begin{array}{l}\mathscr{D} \\
0 \\
0 \\
\dot{\infty}\end{array}$ & $\begin{array}{l}\hat{a} \\
\text { ơ } \\
\dot{+}\end{array}$ & $\begin{array}{l}\text { Lे } \\
\infty \\
\dot{m}\end{array}$ & $\begin{array}{l}\text { ஸे } \\
\stackrel{\sim}{+}\end{array}$ & $\begin{array}{l}\text { Oे } \\
\stackrel{+}{+} \\
\dot{+}\end{array}$ & $\begin{array}{l}\stackrel{\text { }}{N} \\
\stackrel{\sim}{\sim} \\
+\end{array}$ & $\begin{array}{l}\hat{\partial} \\
\text { ơ } \\
\dot{\sigma}\end{array}$ & $\begin{array}{l}\overrightarrow{-} \\
\dot{\sigma} \\
\dot{n}\end{array}$ & $\begin{array}{l}\text { N } \\
\infty \\
\dot{\sigma}\end{array}$ \\
\hline$\stackrel{\text { mे }}{\mapsto}$ & फे & $\stackrel{0}{\circ}$ & 국. & 고. & 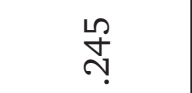 & 롱 & ஓి & $\begin{array}{l}0 \\
\text { Lి }\end{array}$ \\
\hline$\underset{F}{\stackrel{\Xi}{F}}$ & âे & $\underset{ }{\stackrel{g}{f}}$ & 苫 & $\begin{array}{l}\text { } \\
\stackrel{\infty}{+}\end{array}$ & $\stackrel{\infty}{\circ}$ & $\stackrel{\overbrace{}}{\sim}$ & ๗ి & ஸิ \\
\hline$\stackrel{f}{+}$ & $\stackrel{0}{\stackrel{2}{N}}$ & $\stackrel{R}{\stackrel{R}{~}}$ & $\hat{\imath}$ & 命 & ஜ̊ & స్త్ర & $\begin{array}{l}\infty \\
\text { مิ }\end{array}$ & $\begin{array}{l}\infty \\
\text { L } \\
0\end{array}$ \\
\hline $\begin{array}{l}\text { No } \\
\text { ก? }\end{array}$ & $\stackrel{\widehat{\overbrace{}}}{\neg}$ & $\stackrel{\infty}{\stackrel{0}{\circ}}$ & $\begin{array}{l}\infty \\
\text { లి }\end{array}$ & $\hat{\sigma}$ & $\stackrel{尺}{\curvearrowright}$ & $\begin{array}{l}\vec{b} \\
\text { ஸे }\end{array}$ & 옹 & \begin{tabular}{l}
$\infty$ \\
$\infty$ \\
\hdashline
\end{tabular} \\
\hline 옴 & ֻి & 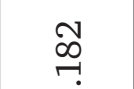 & $\stackrel{\text { Ln }}{\underset{1}{r}}$ & ペ & $\stackrel{\widehat{~}}{\rightarrow}$ & $\begin{array}{l}\text { ڤొ } \\
\text { ஸ̣ }\end{array}$ & $\hat{\sigma}$ & స్ \\
\hline 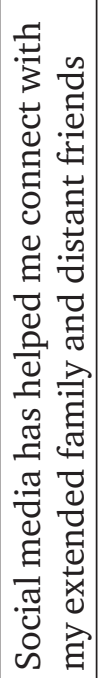 & 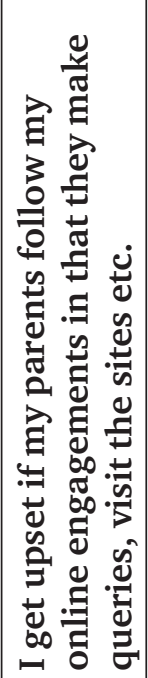 & 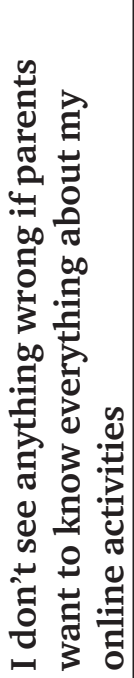 & 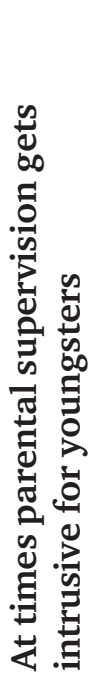 & 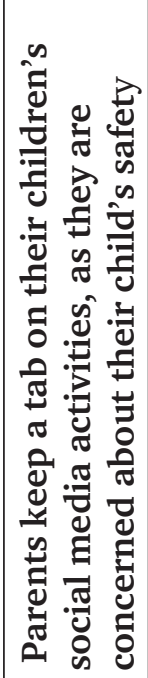 & 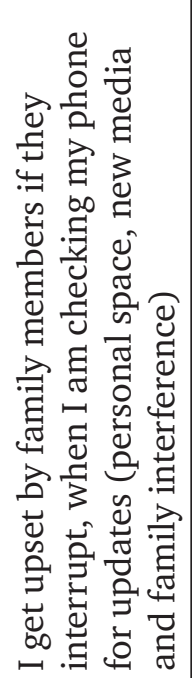 & 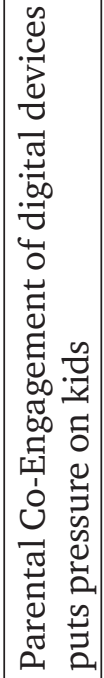 & 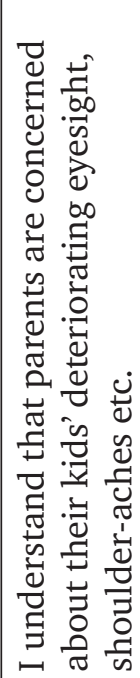 & 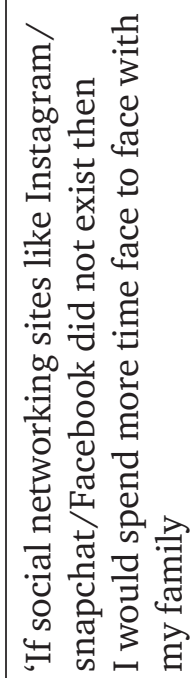 \\
\hline
\end{tabular}




\begin{tabular}{|c|c|c|c|c|c|c|c|c|}
\hline $\begin{array}{l}\stackrel{\infty}{\hat{b}} \\
\stackrel{+}{-}\end{array}$ & $\underset{\sim}{\stackrel{\curvearrowright}{\sim}}$ & $\begin{array}{l}\text { L } \\
\text { \& } \\
\text { - }\end{array}$ & $\begin{array}{l}0 \\
\stackrel{a}{\sigma} \\
-\end{array}$ & $\begin{array}{l}\hat{\alpha} \\
\infty \\
\text { - }\end{array}$ & $\begin{array}{l}\stackrel{0}{\infty} \\
\stackrel{\Gamma}{r}\end{array}$ & & & \\
\hline $\begin{array}{l}\text { ᄋे } \\
\text { ஓ }\end{array}$ & $\begin{array}{l}\text { } \\
\stackrel{+}{+}\end{array}$ & $\begin{array}{l}\infty \\
\stackrel{0}{\circ} \\
\stackrel{0}{\forall}\end{array}$ & $\begin{array}{l}\underset{\sigma}{+} \\
\text { m. }\end{array}$ & $\begin{array}{l}\infty \\
\infty \\
\circ \\
\dot{\sigma}\end{array}$ & 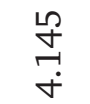 & & & $\dot{д}$ \\
\hline$\stackrel{m}{\dot{f}}$ & ๗ి & $\stackrel{9}{\stackrel{-}{\digamma}}$ & 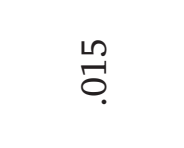 & జ్రి & શิ & 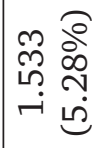 & 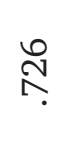 & 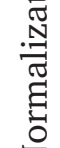 \\
\hline $\begin{array}{c}n \\
\text { ก̊ } \\
\end{array}$ & 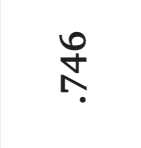 & 守 & ஜֶరి & $\begin{array}{l}\stackrel{0}{7} \\
\rightleftharpoons\end{array}$ & $\begin{array}{l}\infty \\
\infty \\
0 \\
0\end{array}$ & 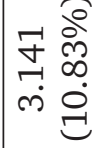 & $\begin{array}{l}0 \\
\infty \\
\infty\end{array}$ & 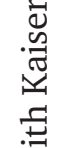 \\
\hline $\begin{array}{l}\text { ณิ } \\
\text { ஸे }\end{array}$ & 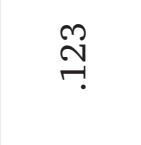 & $\stackrel{\infty}{\circ}$ & 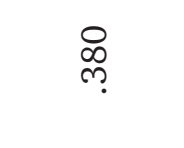 & $\begin{array}{l}\stackrel{7}{r} \\
r\end{array}$ & $\begin{array}{l}\infty \\
\text { 1n } \\
\text { ஸి }\end{array}$ & 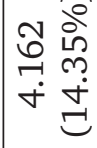 & $\begin{array}{l}\text { oे } \\
\infty\end{array}$ & : \\
\hline 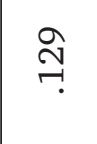 & $\stackrel{\infty}{\stackrel{\infty}{r}}$ & 옹 & $\begin{array}{l}\infty \\
\sigma \\
\sigma\end{array}$ & $\begin{array}{l}\infty \\
\stackrel{0}{\longrightarrow}\end{array}$ & $\begin{array}{l}\infty \\
\stackrel{\infty}{\rightarrow}\end{array}$ & 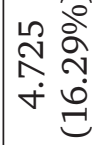 & \&̊ & $\sum_{0}^{5}$ \\
\hline ڤે & $\stackrel{\mathrm{N}}{\stackrel{\mathrm{T}}{.}}$ & $\underset{⿱ 亠}{\stackrel{+}{*}}$ & bo & $\begin{array}{l}m \\
\text { In }\end{array}$ & 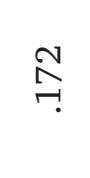 & 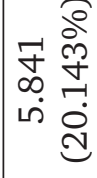 & ga & 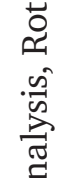 \\
\hline 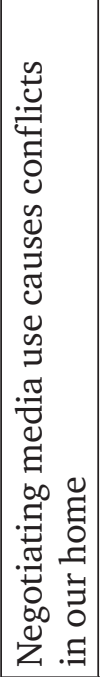 & 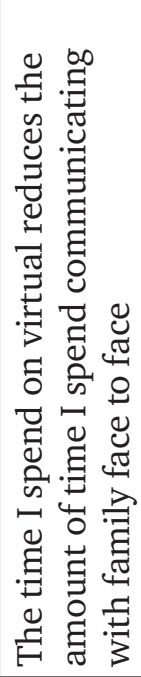 & 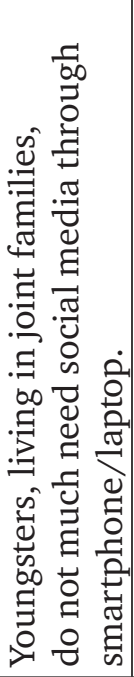 & 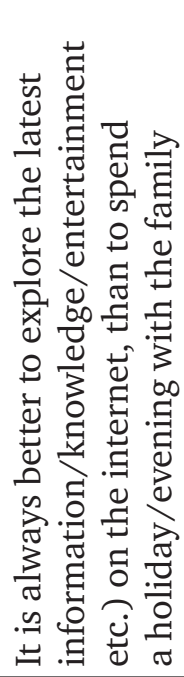 & 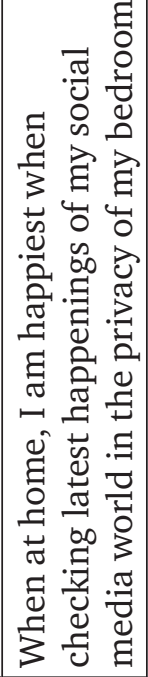 & 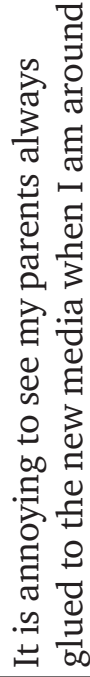 & 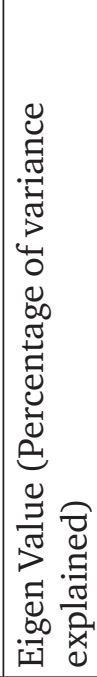 & 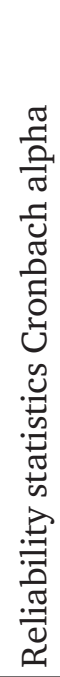 & 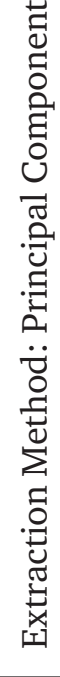 \\
\hline
\end{tabular}




\section{Appendix II \\ ANOVA result \\ Parental coengagement puts pressure on youngsters}

ANOVA

VAR00001

\begin{tabular}{|l|c|c|c|c|c|}
\hline & $\begin{array}{c}\text { Sum of } \\
\text { Squares }\end{array}$ & df & $\begin{array}{c}\text { Mean } \\
\text { Square }\end{array}$ & F & Sig. \\
\hline Between Groups & 70.371 & 4 & 17.593 & 8.223 & .000 \\
\hline Within Groups & 1298.706 & 607 & 2.140 & & \\
\hline Total & 1369.077 & 611 & & & \\
\hline
\end{tabular}

VAR00001

\section{Descriptives}

\begin{tabular}{|c|c|c|c|c|c|c|c|c|}
\hline & \multirow{2}{*}{$\mathrm{N}$} & \multirow{2}{*}{ Mean } & \multirow{2}{*}{$\begin{array}{c}\text { Std. } \\
\text { Deviation }\end{array}$} & \multirow{2}{*}{$\begin{array}{l}\text { Std. } \\
\text { Error }\end{array}$} & \multicolumn{2}{|c|}{$\begin{array}{l}\text { 95\% Confidence } \\
\text { Interval for Mean }\end{array}$} & \multirow{2}{*}{ Minimum } & \multirow{2}{*}{ Maximum } \\
\hline & & & & & $\begin{array}{l}\text { Lower } \\
\text { Bound }\end{array}$ & $\begin{array}{l}\text { Upper } \\
\text { Bound }\end{array}$ & & \\
\hline $\begin{array}{l}13-15 \\
\text { years }\end{array}$ & 185 & 5.0973 & .94480 & .06946 & 4.9603 & 5.2343 & 3.00 & 7.00 \\
\hline $15-17$ & 89 & 4.9326 & 1.09542 & .11611 & 4.7018 & 5.1633 & 2.00 & 7.00 \\
\hline $17-19$ & 68 & 4.0882 & 1.87470 & .22734 & 3.6345 & 4.5420 & 1.00 & 7.00 \\
\hline $19-21$ & 187 & 4.5134 & 1.76391 & .12899 & 4.2589 & 4.7678 & 1.00 & 7.00 \\
\hline $21-22$ & 83 & 4.4699 & 1.61802 & .17760 & 4.1166 & 4.8232 & 1.00 & 7.00 \\
\hline Total & 612 & 4.6977 & 1.49690 & .06051 & 4.5789 & 4.8165 & 1.00 & 7.00 \\
\hline
\end{tabular}

\section{GET UPSET IF PARENTS FOLLOW MY ONLINE ENGAGEMENTS}

ANOVA

VAR00002

\begin{tabular}{|l|c|c|c|c|c|}
\hline & $\begin{array}{c}\text { Sum } \\
\text { of Squares }\end{array}$ & df & $\begin{array}{c}\text { Mean } \\
\text { Square }\end{array}$ & F & Sig. \\
\hline $\begin{array}{l}\text { Between } \\
\text { Groups }\end{array}$ & 237.858 & 4 & 59.464 & 28.349 & .000 \\
\hline $\begin{array}{l}\text { Within } \\
\text { Groups }\end{array}$ & 1273.219 & 607 & 2.098 & & \\
\hline Total & 1511.077 & 611 & & & \\
\hline
\end{tabular}




\section{Descriptives}

VAR00002

\begin{tabular}{|c|c|c|c|c|c|c|c|c|}
\hline & \multirow[t]{2}{*}{$\mathrm{N}$} & \multirow{2}{*}{ Mean } & \multirow{2}{*}{$\begin{array}{c}\text { Std. } \\
\text { Deviation }\end{array}$} & \multirow{2}{*}{$\begin{array}{l}\text { Std. } \\
\text { Error }\end{array}$} & \multicolumn{2}{|c|}{$\begin{array}{l}\text { 95\% Confidence } \\
\text { Interval f } \\
\text { or Mean }\end{array}$} & \multirow[t]{2}{*}{ Minimum } & \multirow[t]{2}{*}{ Maximur } \\
\hline & & & & & $\begin{array}{l}\text { Lower } \\
\text { Bound }\end{array}$ & \begin{tabular}{|l|} 
Upper \\
Bound
\end{tabular} & & \\
\hline $\begin{array}{l}13-15 \\
\text { years }\end{array}$ & 185 & 5.3243 & .94564 & .06953 & 5.1872 & 5.4615 & 2.00 & 7.00 \\
\hline $15-17$ & 89 & 5.4382 & .82510 & .08746 & 5.2644 & 5.6120 & 2.00 & 7.00 \\
\hline $17-19$ & 68 & 3.8529 & 1.73863 & .21084 & 3.4321 & 4.2738 & 1.00 & 7.00 \\
\hline $19-21$ & 187 & 4.3690 & 1.78033 & .13019 & 4.1121 & 4.6258 & 1.00 & 7.00 \\
\hline $21-22$ & 83 & 3.9398 & 1.76931 & .19421 & 3.5534 & 4.3261 & 1.00 & 7.00 \\
\hline Total & 612 & 4.6977 & 1.57262 & .06357 & 4.5729 & 4.8226 & 1.00 & 7.00 \\
\hline
\end{tabular}

\section{At times parental supervision gets intrusive}

\section{ANOVA}

VAR00003

\begin{tabular}{|l|c|c|c|c|c|}
\hline & Sum of Squares & Df & Mean Square & F & Sig. \\
\hline Between Groups & 209.314 & 4 & 52.328 & 16.455 & .000 \\
\hline Within Groups & 1930.273 & 607 & 3.180 & & \\
\hline Total & 2139.587 & 611 & & & \\
\hline
\end{tabular}

\section{Descriptives}

VAR00003

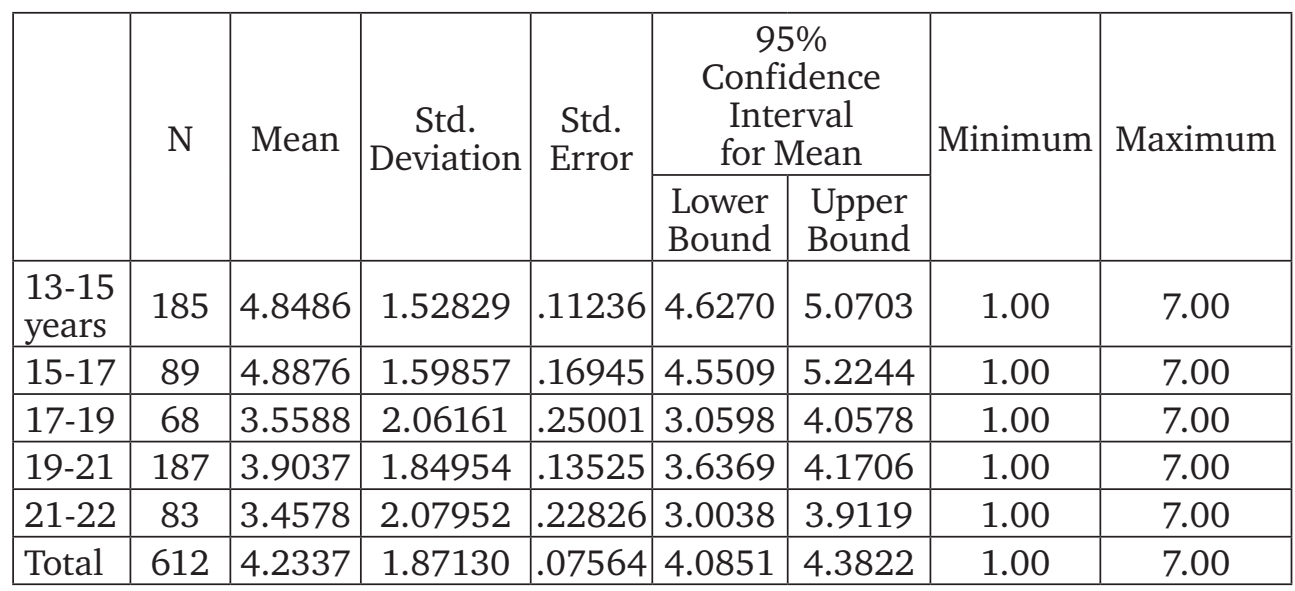




\section{GET UPSET BY FAMILY MEMBERS IF THEY INTERRUPT WHEN I AM WHEN I AM CHECKING MY PHONE FOR UPDATES}

\section{ANOVA}

VAR00004

\begin{tabular}{|l|c|c|c|c|c|}
\hline & $\begin{array}{c}\text { Sum } \\
\text { of Squares }\end{array}$ & df & $\begin{array}{c}\text { Mean } \\
\text { Square }\end{array}$ & F & Sig. \\
\hline $\begin{array}{l}\text { Between } \\
\text { Groups }\end{array}$ & 73.873 & 4 & 18.468 & 6.399 & .000 \\
\hline Within Groups & 1751.892 & 607 & 2.886 & & \\
\hline Total & 1825.765 & 611 & & & \\
\hline
\end{tabular}

\section{Descriptives}

VAR00004

\begin{tabular}{|c|c|c|c|c|c|c|c|c|}
\hline & \multirow[t]{2}{*}{$\mathrm{N}$} & \multirow[t]{2}{*}{ Mean } & \multirow[t]{2}{*}{$\begin{array}{c}\text { Std. } \\
\text { Deviation }\end{array}$} & \multirow[t]{2}{*}{$\begin{array}{l}\text { Std. } \\
\text { Error }\end{array}$} & \multicolumn{2}{|c|}{$\begin{array}{c}95 \% \\
\text { Confidence } \\
\text { Interval } \\
\text { for Mean } \\
\end{array}$} & \multirow[t]{2}{*}{ Minimum } & \multirow[t]{2}{*}{ Maximum } \\
\hline & & & & & $\begin{array}{l}\text { Lower } \\
\text { Bound }\end{array}$ & $\begin{array}{l}\text { Upper } \\
\text { Bound }\end{array}$ & & \\
\hline $\begin{array}{l}13-15 \\
\text { years }\end{array}$ & 185 & 4.5730 & 1.52740 & .11230 & 4.3514 & 4.7945 & 1.00 & 7.00 \\
\hline $15-17$ & 89 & 4.9326 & 1.46006 & .15477 & 4.6250 & 5.2401 & 1.00 & 7.00 \\
\hline 17-19 & 68 & 3.8382 & 1.97454 & .23945 & 3.3603 & 4.3162 & 1.00 & 7.00 \\
\hline $19-21$ & 187 & 4.2299 & 1.79772 & .13146 & 3.9706 & 4.4893 & 1.00 & 7.00 \\
\hline $21-22$ & 83 & 3.9398 & 1.82362 & .20017 & 3.5416 & 4.3380 & 1.00 & 7.00 \\
\hline Total & 612 & 4.3529 & 1.72863 & .06988 & 4.2157 & 4.4902 & 1.00 & 7.00 \\
\hline
\end{tabular}

It is always better to explore the latest information/knowledge / entertainment on the internet than to spend a holday/ evening with the family

\section{ANOVA}

VAR00005

\begin{tabular}{|l|c|c|c|c|c|}
\hline & $\begin{array}{c}\text { Sum } \\
\text { of Squares }\end{array}$ & df & $\begin{array}{c}\text { Mean } \\
\text { Square }\end{array}$ & F & Sig. \\
\hline $\begin{array}{l}\text { Between } \\
\text { Groups }\end{array}$ & 98.763 & 4 & 24.691 & 8.276 & .000 \\
\hline Within Groups & 1811.001 & 607 & 2.984 & & \\
\hline Total & 1909.765 & 611 & & & \\
\hline
\end{tabular}




\section{Descriptives}

VAR00005

\begin{tabular}{|c|c|c|c|c|c|c|c|c|}
\hline & \multirow[t]{2}{*}{$\mathrm{N}$} & \multirow[t]{2}{*}{ Mean } & \multirow[t]{2}{*}{$\begin{array}{c}\text { Std. } \\
\text { Deviation }\end{array}$} & \multirow[t]{2}{*}{$\begin{array}{l}\text { Std. } \\
\text { Error }\end{array}$} & \multicolumn{2}{|c|}{$\begin{array}{c}95 \% \\
\text { Confidence } \\
\text { Interval } \\
\text { for Mean }\end{array}$} & \multirow[t]{2}{*}{ Minimum } & \multirow[t]{2}{*}{ Maximur } \\
\hline & & & & & $\begin{array}{l}\text { Lower } \\
\text { Bound }\end{array}$ & $\begin{array}{l}\text { Upper } \\
\text { Bound }\end{array}$ & & \\
\hline $\begin{array}{l}13-15 \\
\text { years }\end{array}$ & 185 & 4.8216 & 1.65029 & .12133 & 4.5822 & 5.0610 & 1.00 & 7.00 \\
\hline $15-17$ & 89 & 4.7079 & 1.53891 & .16312 & 4.3837 & 5.0320 & 1.00 & 7.00 \\
\hline $17-19$ & 68 & 3.8529 & 2.00942 & .24368 & 3.3666 & 4.3393 & 1.00 & 7.00 \\
\hline 19-21 & 187 & 4.1176 & 1.68071 & .12291 & 3.8752 & 4.3601 & 1.00 & 7.00 \\
\hline $21-22$ & 83 & 3.8675 & 1.93032 & .21188 & 3.4460 & 4.2890 & 1.00 & 7.00 \\
\hline Total & 612 & 4.3529 & 1.76795 & .07147 & 4.2126 & 4.4933 & 1.00 & 7.00 \\
\hline
\end{tabular}

\section{When at home, I am happiest IN my social media world IN THE PRIVACY OF MY BEDROOM}

\section{ANOVA}

VAR00006

\begin{tabular}{|l|c|c|c|c|c|}
\hline & $\begin{array}{c}\text { Sum of } \\
\text { Squares }\end{array}$ & $\mathrm{df}$ & $\begin{array}{c}\text { Mean } \\
\text { Square }\end{array}$ & $\mathrm{F}$ & Sig. \\
\hline Between Groups & 131.293 & 4 & 32.823 & 11.208 & .000 \\
\hline Within Groups & 1777.705 & 607 & 2.929 & & \\
\hline Total & 1908.998 & 611 & & & \\
\hline
\end{tabular}

VAR00006

\section{Descriptives}

\begin{tabular}{|c|c|c|c|c|c|c|c|c|}
\hline & \multirow[t]{2}{*}{$\mathrm{N}$} & \multirow[t]{2}{*}{ Mean } & \multirow[t]{2}{*}{$\begin{array}{c}\text { Std. } \\
\text { Deviation }\end{array}$} & \multirow[t]{2}{*}{$\begin{array}{l}\text { Std. } \\
\text { Error }\end{array}$} & \multicolumn{2}{|c|}{$\begin{array}{c}95 \% \\
\text { Confidence } \\
\text { Interval } \\
\text { for Mean }\end{array}$} & \multirow[t]{2}{*}{ Minimum } & \multirow[t]{2}{*}{ Maximum } \\
\hline & & & & & $\begin{array}{l}\text { Lower } \\
\text { Bound }\end{array}$ & $\begin{array}{l}\text { Upper } \\
\text { Bound }\end{array}$ & & \\
\hline $\begin{array}{l}13-15 \\
\text { years }\end{array}$ & 185 & 4.9243 & 1.47983 & 10880 & 4.7097 & 5.1390 & 1.00 & 7.00 \\
\hline $15-17$ & 89 & 4.9438 & 1.54007 & .16325 & 4.6194 & 5.2682 & 1.00 & 7.00 \\
\hline $17-19$ & 68 & 3.8088 & 1.76413 & .21393 & 3.3818 & 4.2358 & 1.00 & 7.00 \\
\hline $19-21$ & 187 & 4.2246 & 1.82363 & .13336 & 3.9615 & 4.4877 & 1.00 & 7.00 \\
\hline $21-22$ & 83 & 3.8434 & 2.03315 & .22317 & 3.3994 & 4.2873 & 1.00 & 7.00 \\
\hline Total & 612 & 4.4428 & 1.76759 & .07145 & 4.3025 & 4.5831 & 1.00 & 7.00 \\
\hline
\end{tabular}


It is annoying to see my parents glued to the internet ANOVA

VAR00007

\begin{tabular}{|l|c|c|c|c|c|}
\hline & $\begin{array}{c}\text { Sum } \\
\text { of Squares }\end{array}$ & $\mathrm{df}$ & $\begin{array}{c}\text { Mean } \\
\text { Square }\end{array}$ & $\mathrm{F}$ & Sig. \\
\hline $\begin{array}{l}\text { Between } \\
\text { Groups }\end{array}$ & 51.690 & 4 & 12.922 & 5.082 & .000 \\
\hline $\begin{array}{l}\text { Within } \\
\text { Groups }\end{array}$ & 1543.622 & 607 & 2.543 & & \\
\hline Total & 1595.312 & 611 & & & \\
\hline
\end{tabular}

\section{Descriptives}

VAR00007

\begin{tabular}{|c|c|c|c|c|c|c|c|c|}
\hline & \multirow[t]{2}{*}{$\mathrm{N}$} & \multirow[t]{2}{*}{ Mean } & \multirow[t]{2}{*}{$\begin{array}{c}\text { Std. } \\
\text { Deviation }\end{array}$} & \multirow[t]{2}{*}{$\begin{array}{l}\text { Std. } \\
\text { Error }\end{array}$} & \multicolumn{2}{|c|}{$\begin{array}{c}95 \% \\
\text { Confidence } \\
\text { Interval } \\
\text { for Mean }\end{array}$} & \multirow[t]{2}{*}{ Minimum } & \multirow[t]{2}{*}{ Maximum } \\
\hline & & & & & $\begin{array}{l}\text { Lower } \\
\text { Bound }\end{array}$ & $\begin{array}{l}\text { Upper } \\
\text { Bound }\end{array}$ & & \\
\hline $\begin{array}{l}13-15 \\
\text { years }\end{array}$ & 185 & 4.6811 & 1.30672 & .09607 & 4.4915 & 4.8706 & 1.00 & 7.00 \\
\hline $15-17$ & 89 & 4.6292 & 1.36833 & .14504 & 4.3410 & 4.9175 & 1.00 & 7.00 \\
\hline $17-19$ & 68 & 3.7500 & 1.79863 & .21812 & 3.3146 & 4.1854 & 1.00 & 7.00 \\
\hline 19-21 & 187 & 4.3476 & 1.76039 & .12873 & 4.0936 & 4.6016 & 1.00 & 7.00 \\
\hline $21-22$ & 83 & 4.2048 & 1.81967 & 19973 & 3.8075 & 4.6022 & 1.00 & 7.00 \\
\hline Total & 612 & 4.4036 & 1.61585 & .06532 & 4.2753 & 4.5319 & 1.00 & 7.00 \\
\hline
\end{tabular}

\section{References}

ALZAHRANI, S. \& BACH, C. (2014). Impact of social media on personality development. International Journal of Innovation and Scientific Research, 3(2), pp. 111-116.

Australian communications and media authority (2008). Internet use and social networking by young people. Media and Communications in Australian Families series, 1. Available from: www.acma.au

BEST, P., MANKTELOW, R., \& TAYLOR, B. (2014). Online communication, social media and adolescent wellbeing: A systematic narrative review. Children and YouthServicesReview, 41,pp.27-36.DOI: 10.1016/j.childyouth.2014.03.001

BOYD, D. M. \&ELLISON, N. B. (2007). Social network sites: Definition, history, and scholarship. Journal of Computer Mediated Communication, 13(1), pp. 210230. Available from: https://doi.org/10.1111/j.1083-6101.2007.00393.x 
BUCKINGHAM, D. (2008). Youth identity and digital media. Cambridge, MA, The MIT Press, 2008.

CHADDHA, R. \& DEB, K. S. (2013). Indian family systems, collectivistic society and psychotherapy. Indian Journal of Psychiatry, 55(6), pp. 299-309.

CHO, C.-H. \& CHEON, H. J. (2005). Children's exposure to negative Internet content: Effects of family context. Journal of Broadcasting \& Electronic Media, 49(4), pp. 488-509. DOI: 10.1207/s15506878jobem4904_8

CHRISTOFFERSON, J. P. (2016). How is social networking sites effecting teen's social and emotional development: A systemic review. Master of Social Work Clinical Research Papers, 650. Available from: http://sophia.stkate.edu/ msw_papers/650

CINGEL, D. P., WARTELLA, E., \& KRCMAR, M. (2014). The role of adolescent development in social networking site use: Theory and evidence. Journal of Youth Development, 9(1).

EYNON, R. \& HELSPER, E. (2015). Family dynamics and Internet use in Britain: What role do children play in adults' engagement with the Internet? Information, Communication \& Society, 18(2), pp. 156-171. DOI: 10.1080/1369118X.2014.942344

FRYDENBERG, E. (2008). Adolescent coping: Advances in theory, research, and practice. Routledge, Psychology Press, New York.

GAUDIN, S. (2009). Social networks cutting into family time; Increasing use of social networks are making users less social with their families. Available from: https://www.computerworld.com/article/2525517/internet/socialnetworks-cutting-into-family-time.html

GREGORY, S. (2009). Changing family structure in India. Impact and implications. Journal of the Institute for Research in Social Sciences and Humanities, 4(1), pp. 77-93.

JENKINS, H., CLINTON, K., PURUSHOTMA, R., ROBISON, A. J., WEIGEL, M. (2006). Confronting the challenges of participatory culture: Media education for the 21st century. Chicago, Illinois, The MacArthur Foundation.

JENNINGS, N. (2017). Media and families: Looking ahead. Journal of Family Communication, 17(3), pp. 203-207.

KNUT J. A. (2015). India's middle classes in contemporary India. Routledge. Available from: https://www.routledgehandbooks.com/doi/ 10.4324/9781315682570.ch15

LEE, D. H. (2013). Smartphones, mobile social space, and new sociality in Korea. Mobile media \& communication, 1(3), pp. 269-284. DOI: $10.1177 / 2050157913486790$ 
LEUNG, L., \& WEI, R. (2000). More than just talk on the move: The uses and gratifications of the cellular phone. Journalism \& Mass Communication Quarterly, 77.

LIVINGSTONE, S. (1999). New media, new audiences. New Media and Society, pp. 59-66.

LIVINGSTONE, S. \& BOVILL, M. (1999). Young people, new media: Report of the research project Children Young People and the Changing Media Environment. Research report, Department of Media and Communications, London School of Economics and Political Science, London, UK.

LIVINGSTONE, S. (2003). Children's use of the internet: Reflections on the emerging research agenda. London: LSE Research Online.

LIVINGSTONE, S. (2005). Mediating the public/private boundary at home: Children's use of the Internet for privacy and participation. Journal of Media Practice, 6(1), pp. 41-51.

MADGE, C. \& O'CONNOR, H. (2006). Parenting gone wired: Empowerment of new mothers on the internet? Social \& Cultural Geography, 7(2), pp. 199220. DOI: $10.1080 / 14649360600600528$

MADIANOU, M. \& MILLER, D. (2012). Polymedia: Towards a new theory of digital media in interpersonal communication. International Journal of Cultural Studies, 16(2), pp. 169-187.

MANAGO, A. M., TAYLOR, T., \& GREENFIELD, P. M. (2012). Me and my 400 friends: The anatomy of college students' Facebook networks, their communication patterns, and well-being. Developmental Psychology. DOI: $10.1037 / \mathrm{a} 0026338$

MANHAS, S. \& CHAMBYAL, D. (2017). Smartphone usage and dependence among adolescents and young adults of Jammu. International Journal of Applied Home Science, 4 (7-8), pp. 473-488.

MCBRIDE, D. (2011). Risks and benefits of social media for children and adolescents. Journal of Pediatric Nursing, 26(5), pp. 498-499.

MCGRATH, S. (2012). The impact of new media technologies social interactions in the household. Availablefrom: https://www.maynoothuniversity. ie/sites/default/files/assets/document/SiobhanMcGrath.pdf

MCMILLAN, S. J. \& MORRISON, M. (2006). Coming of age with the internet: A qualitative exploration of how the internet has become an integral part of young people's lives. New Media Society.

MENDELSON, A. L. \& PAPACHARISSI, Z. (2010). Look at us: Collective narcissism in college student Facebook photo galleries. In: Z. Papacharissi, The networked self: Identity, community and culture on social network sites. Routledge. 
MESCH, G. S. (2006). The Internet and youth culture. The Journal of Family Communication, 6(2).

MESCH, G. S. (2009). Family relations and the Internet: Exploring a family boundaries approach. Journal of Family Communication, 6(2), pp. 119-138. DOI: 10.1207/s15327698jfc0602_2

MOSHMAN, D. (1999). Adolescent psychological development: Rationality, morality and identity. The Psychology Press, Taylor and Francis Group.

NARASIMHAMURTHY, N. (2014). Contemporary media - a new generation information and entertainment medium. IOSR Journal of Humanities And Social Science (IOSR-JHSS), 19(6), pp. 46-54.

NEWHAM, M. (201. Is social networking media affecting social interaction between users? Available from: https://esource.dbs.ie/bitstream/ handle/10788/344/ba_newham_m_2012.pdf?sequence $=1$

NIKKEN, P. (2019). Parents' instrumental use of media in childrearing: Relationships with confidence in parenting, and health and conduct problems in children. Journal of Child and Family Studies, 28, pp. 531-546. Available from: https://doi.org/10.1007/s10826-018-1281-3

NIRANJAN, S., SUREENDER, S., \& RAO, G. R. (1998). Family structure in India - evidence from NFHS. Demography India, 27(2), pp. 287-300.

QI, J., MONOD, E., FANG, B., DENG, S. (2018). Theories of social media: Philosophical foundations. Engineering, 4(1), pp. 94-102.

QUAN-HAASE, A. \& YOUNG, A. L. (2010). Uses and gratifications of social media: A comparison of Facebook and instant messaging, Bulletin of Science, Technology \& Society, Sage Publications. DOI: 10.1177/0270467610380009

RAJAGIRI, E. (2014). Indian teenagers and their family relations in the social networking. Journal of Social Development, 6(1).

ROBINSON, L. \& SCHULZ. J. (2013). Net time negotiations within the family. Information, Communication \& Society, 16(4), pp. 542-560. DOI: 10.1080/1369118X.2013.777761

SMITH, J., HEWITT, B., \& SKRBIS, Z. (2015). Digital socialization: Young people's changing value orientations towards internet use between adolescence and early adulthood. Information, Communication \& Society, 18(9), pp. 10221038. DOI: 10.1080/1369118X.2015.1007074

SPONCIL, M. \& GITIMU, P. (2012). Use of social media by college students: Relationship to communication and self-concept. Journal of Technology Research.

SRIRAM, R. (1993). Family studies in India: Appraisal and new directions. In: T. S. Saraswati \& B. Kaur, Human development and family studies in India: An agenda for research and policy. New Delhi, India, Sage Publishers. 
STEINBERG, L. (2005). Cognitive and affective development in adolescence. Trends in Cognitive Sciences, 9(2).

VAIDYA, A., PATHAK, V., \& VAIDYA, A. (2016). Mobile phone usage among youth. International Journal of Applied Research and Studies (iJARS), 5(3).

VARGHESE, T. \& NIVEDHITHA, D. (2014). Indian teenagers and their family relations in the social networking era. Rajagiri Journal of Social Development, 6(1), pp. 29-48.

VIJAYALAKSHMI, P. \& DURGA, B. V. (2006). Internet use, Indian culture and gender variations. Media Asia, 33(3-4). 